\title{
PENGEMBANGAN MODEL BIMBINGAN KELOMPOK MELALUI METODE PROBLEM SOLVING UNTUK MENINGKATKAN MOTIVASI BELAJAR SISWA
}

\author{
Novi Andriati ${ }^{1)}$, Rustam ${ }^{2)}$ \\ ${ }^{1)}$ IKIP PGRI Pontianak, Pontianak, Indonesia \\ E-mail: novieandriaty@yahoo.co.id \\ ${ }^{2)}$ IKIP PGRI Pontianak, Pontianak, Indonesia \\ E-mail: rustammunif@yahoo.co.id
}

\begin{abstract}
Abstrak. Tujuan penelitian yaitu menghasilkan model bimbingan kelompok dengan metode problem solving untuk meningkatkan motivasi belajar siswa SMA. Penelitian ini menggunakan metode Research and Development (R\&D). Dari hasil uji coba lapangan, kemampuan motivasi belajar siswa SMA mengalami perkembangan setelah mengikuti kegiatan bimbingan kelompok dengan metode problem solving. Keseluruhan nilai asymp sig 0,028 $<0,05$ maka Ho ditolak dan Ha diterima, sehingga dapat disimpulkan bahwa bimbingan kelompok dengan metode problem solving efektif untuk meningkatkan motivasi belajar siswa. Saran: penggunaan model bimbingan kelompok dengan metode problem solving sebaiknya dapat dimulai dengan mendiagnosa secara cermat kondisi objektif siswa yang akan dijadikan sebagai anggota kelompok, metode problem solving yang digunakan sebagai dasar perlakuan mengandung nilai kebermanfaatan dan kebermaknaan bagi siswa SMA serta guru dapat menggunakan model bimbingan kelompok dengan metode problem solving untuk meningkatkan motivasi belajar siswa SMA.
\end{abstract}

Kata Kunci: Model Bimbingan Kelompok; Metode Problem Solving; Motivasi Belajar Siswa SMA

\section{Pendahuluan}

[1] Guru bimbingan dan konseling (konselor) adalah seorang pendidik yang memfasilitasi perkembangan seluruh potensi siswa dari berbagai aspek, mulai dari aspek pribadi, psikologi, maupun dari aspek sosial. Guru pembimbing memberikan bimbingan dalam menyiapkan siswa menentukan pilihannya secara mandiri dan dapat menumbuhkan motivasi peserta didik dalam belajar, karena motivasi merupakan hal yang penting dalam proses pembelajaran. Tidak akan terjadi proses pembelajaran jika tidak ada motivasi yang kuat dari peserta didik. Tingkat motivasi belajar peserta didik tidak sama antara satu orang dengan orang lain. Seorang guru pembimbing harus bisa mengupayakan agar peserta didik termotivasi untuk belajar. Hasil belajar akan menjadi optimal kalau ada motivasi. Semakin tepat motivasi yang diberikan, akan semakin berhasil pula pelajaran yang dipelajarinya. Motivasi adalah kekuatan-kekuatan atau tenaga-tenaga yang dapat memberikan dorongan kepada kegiatan belajar anak". Kegiatan memotivasi kelihatannya memang sepele akan tetapi, seorang anak bisa bangkit dan berubah adalah bukan karena kepintaran dan dilihat dari nilai akademiknya saja, melainkan motivasi yang bersumber dari dirinya, melalui kesadaran dan pemikiran dirinya, dapat juga dari luar diri peserta didik, (dari orang tua, guru-guru, teman-teman, bahkan dari masyarakat dan media massa). Guru pembimbing merupakan orang yang harus mengetahui tentang perkembangan dan kemajuan motivasi belajar peserta didik. Guru pembimbing pula yang mengetahui dengan pasti ada tidaknya masalah yang dihadapi peserta didik dengan kata lain guru pembimbing adalah sumber informasi tentang berbagai hal yang berkaitan dengan peserta didik. 
Guru pembimbing memiliki peranan sebagai motivator dan fasilisator dalam rangka meningkatkan motivasi belajar peserta didik dalam proses belajar mengajar dengan memberikan layanan bimbingan konseling khususnya melalui layanan bimbingan kelompok. Pada layanan bimbingan kelompok, guru pembimbing akan memberikan bahan-bahan materi yang akan dibahas secara bersama oleh anggota kelompok dan masing-masing anggota diberikan kebebasan oleh guru pembimbing untuk memberikan pendapat yang mereka miliki berdasarkan pengetahuan dan pengalaman mereka baik secara pribadi maupun pengalaman orang lain. Pada kegiatan bimbingan kelompok, pemimpin kelompok dapat menggunakan metode pemecahan masalah (problem solving) dalam pelaksanaan bimbingan. Metode problem solving (pemecahan masalah) merupakan suatu cara yang dapat dilakukan oleh guru pembimbing dengan peserta didik untuk berinteraksi, dalam rangka memecahkan permasalahan secara sistematis.

[2] mengatakan bahwa metode pemecahan masalah adalah cara yang dipergunakan oleh guru dalam mengadakan hubungan dengan siswa pada saat berlangsungnya pengajaran untuk memecahkan masalah belajar siswa di kelas. Metode pemecahan masalah merupakan metode yang merangsang berpikir dan menggunakan wawasan tanpa melihat kualitas pendapat yang disampaikan oleh siswa. Dapat disimpulkan bahwa kegiatan belajar yang dimaksudkan disini tidak hanya menulis, menghafal, menghitung dan membaca saja melainkan peserta didik diharapkan mampu berinteraksi secara sadar dengan lingkungannya dan mampu mengemukakan pendapat mereka melalui wawasan yang dimilikinya. Melalui layanan bimbingan kelompok dengan penggunaan metode problem solving, siswa dapat diajak untuk bersama-sama mengemukakan pendapat yang berkenaan dengan sesuatu hal dan membicarakan topik-topik penting, mengembangkan nilai-nilai sikap, tindakan yang nyata untuk mencapai hal-hal yang diinginkan sebagai mana terungkap dalam kelompok, serta dapat mengembangkan langkah-langkah mengenai permasalahan yang dibahas dalam kelompok.

Agar kesukaran-kesukaran dalam kehidupan kelompok itu tidak membawa dampak bagi kegiatan-kegiatan kelompok yang akhirnya akan menghambat perkembangan individu yang bersangkutan, maka dalam setiap usaha pendidikan, kegiatan bimbingan kelompok sangat diperlukan yang hanya dapat dilakukan oleh guru bimbingan konseling. Pada kenyataannya banyak sekolah yang masih belum mengakui keberadaan guru bimbingan dan konseling, serta menganggap bahwa guru pembimbing kurang efisien dalam bekerja sehingga ada beberapa sekolah menempatkan jabatan guru bimbingan dan konseling bukan dari sarjana bimbingan konseling (BK), melainkan guru bidang studi seperti guru pendidikan kewarganegaraan ini terjadi karena pekerjaan guru pembimbing dianggap sangatlah mudah, [3]. Keberadaan guru pembimbing di sekolah kebanyakan hanya dianggap tidak banyak bekerja, karena tidak ada jam mengajar akan tetapi pada proses belajar mengajar sekarang ini guru bimbingan dan konseling ditingkat Sekolah Menengah Pertama dan jenjang Sekolah Menengah Atas diberikan kesempatan untuk masuk kelas dengan tujuan agar dapat memberikan bimbingan dan konseling.

[4] Penelitian ini terbukti bahwa bimbingan konseling dapat meningkatkan motivasi semua target populasi yaitu membantu meningkatkan motivasi siswa dalam melakukan pilihan bidang studi pada tahun pertama sekolah, secara tidak langsung penelitian ini mempunyai tujuan yang sama yaitu selalu meningkatkan motivasi juga meningkatkan kepercayaan diri siswa. [5] Penelitian ini dilaksanakan dalam menganalisis kemampuan siswa belajar melalui bimbingan klasikal. Bimbingan yang diberikan diharapkan siswa bisa memahami tentang pentingnya pengulangan kembali materi yang diberikan oleh guru untuk dilaksanakan dalam proses pembelajaran selanjutnya. Melalui penelitian ini, bimbingan klasikal efektif sebagai analisa kemampuan siswa dalam belajar. [6] Penelitian ini adalah bentuk bimbingan klasikal dalam proses pembelajaran oleh seorang mahasiswa kedokteran dalam mengahadapi pasien yang bunuh diri. Pembimbingnya yaitu seorang dokter menceritakan pengalaman hidupnya sendiri. Cara menangani pasien yang depresi dan tidak memiliki konsep diri sehingga. Melalui penelitian ini, bimbingan klasikal efektif untuk mengatasi pasien yang ingin bunuh diri.

[7] Penelitian ini menyebutkan bahwa masa remaja adalah masa transisi dimana adanya perubahan dari masa anak-anak menuju masa dewasa, pada masa ini banyak gejolak atau perubahan-perubahan yang dialami oleh remaja. Pada masa ini tidak sedikit remaja putri yang berperilaku negatif karena pengaruh lingkungan seperti putus sekolah dan melakukan free sex sehingga banyak gadis yang hamil. Rendahnya kepercayaan diri pada remaja mengakibatkan mudahnya remaja terbawa pengaruh negatif karena tidak yakin akan dirinya. Melalui penelitian eksperimen ini terbukti bahwa konseling kelompok efektif meningkatkan kepercayaan diri pada remaja putri.

Peserta didik yang menampakkan karakteristik tersebut, akan diikut sertakan menjadi anggota dalam layanan bimbingan kelompok dengan maksud meningkatkan motivasi belajar peserta didik. Sehingga yang menjadi harapan penulis dalam penelitian ini adalah dengan adanya peningkatan motivasi belajar peserta didik melalui metode problem solving dalam layanan bimbingan kelompok di Sekolah Menengah Atas di Kota Pontianak pada siswa kelas $\mathrm{X}$, maka hasilnya akan dapat meningkatkan motivasi belajar peserta didik yang baik dan nantinya akan memiliki hasil belajar yang memuaskan.

\section{Metode}

Penelitian ini menggunakan jenis penelitian pengembangan atau Research and Development (R\&D), yaitu jenis penelitian yang digunakan untuk menghasilkan produk tertentu, dan menguji keefektifan produk tersebut [8]. Dasar pertimbangan penggunaan pendekatan ini adalah didasarkan pada prinsip-prinsip dan langkah-langkah sesuai strategi penelitian dan pengembangan efektif untuk mengembangkan dan validasi produk pendidikan.Produk pendidikan yang dapat dihasilkan melalui pendekatan 
penelitian dan pengembangan adalah buku teks, film instruksional, program komputer, metode mengajar, dan berbagai programpendidikan lainnya. Tujuan dari penelitian ini tersusunnya suatu pengembangan model bimbingan kelompok melalui metode problem solving untuk motivasi belajar. Kerangka isi dan komponen model dirancang berdasarkan kajian konsep bimbingan kelompok, kajian konsep metode problem solving, kajian konsep motivasi belajar, serta kajian empiris tentang kondisi faktual bimbingan kelompok di SMA Kota Pontianak, khususnya bimbingan kelompok di SMA Negeri 2 Pontianak. Dengan demikian dapat disimpulkan bahwa metode penelitian ini menggunakan pendekatan penelitian dan pengembangan (research and development). Penelitian pengembangan diarahkan sebagai proses pengembangan dan validasi produk. Produk yang dimaksud adalah sebuah model bimbingan kelompok melalui metode problem solving untuk meningkatkan motivasi belajar siswa kelas X di SMA Negeri 2 Pontianak. Berdasarkan tahapan yang akan dilaksanakan maka secara keseluruhan rancangan yang digunakan dalam penelitian ini adalah rancangan penelitian dan pengembangan (research and development). Langkahlangkah yang seyogyanya ditempuh dalam penelitian pengembangan meliputi: (1) studi pendahuluan, (2) perencanaan, (3) pengembangan model hipotetik, (4) penelaahan model hipotetik, (5) revisi, (6) uji coba terbatas. Jenis instrumen pengumpulan data yang digunakan dalam penelitian ini adalah Pedoman wawancara dan pedoman observasi. Penelitian ini menggunakan dua metode penelitian yaitu kualitatif dan kuantitatif secara terpadu, maka teknik analisa data pun dilakukan secara terpadu. Analisis data dalam penelitian ini diarahkan dalam tiga tahap: tahap pertama, analisis data penelitian pada tahapan ini dilakukan secara kuantitatif dan kualitatif. Prosedur kuantitatif dilakukan dengan menghitung persentase tingkat motivasi belajar. Prosedur kualitatif dilakukan untuk memaknai deskripsi kondisi faktual tentang pelaksanaan bimbingan kelompok di sekolah. Hasil analisis ini dijadikan dasar untuk menyusun model awal. Tahap kedua menggunakan prosedur kualitatif. Bentuk analisisnya adalah uji kelayakan model dengan mempertimbangkan masukan dari validator ahli dan praktisi. Hasil dari analisis ini digunakan untuk melakukan perbaikan dari model awal (model teruji 1). Tahap ketiga, dianalisis dengan prosedur kualitatif dan kuantitatif. Bentuk analisis kualitatif yang dilakukan adalah menelaah proses implementasi model yang dikembangkan. Sedangkan analisis kuantitatif dilakukan dengan menghitung persentase motivasi belajar setelah dikenai model bimbingan kelompokmelalui metode problem solving. Hasil dari analisis ini digunakan sebagai dasar untuk menyusun model akhir bimbingan kelompok melalui metode problem solving untuk meningkatkan motivasi belajar siswa.

\section{HASIL DAN PEMBAHASAN}

A. Hasil

Pelaksanaan bimbingan kelompok di SMA Negeri 2 hanya terbatas pada kegiatan kelompok biasa dengan tidak menggunakan unsur bimbingan kelompok dalam pelaksanaannya serta masih menggabungkan keseluruhan siswa dengan berbagai permasalahannya.Pelaksana kegiatan kelompok di SMA ini adalah guru kelas dengan perlakuan disetiap tahapan-tahapan yang disesuaikan dengan karakteristik masing-masing siswa namun tidak menggunakan teknik yang disesuaikan dengan jenis kemampun siswa dalam belajar, materi yang di sampaikan merupakan materi-meteri umum dan bukan pada aspek pengembangan kecakapan kehidupan sehari-hari. Prosedur pelaksanaan kegiatan kelompok di SMA Negeri 2 Pontianak tidak diawali dengan mengidentifikasi kebutuhan melalui instrumen ataupun non instrumen seperti pada bimbingan kelompok melainkan dengan cara mengklasifikasi secara langsung minat siswa dari kegiatan pendahuluan sebelum digabung dengan siswa kelas yang berbeda. Tahapan pelaksanaan pada kegiatan kelompok yang digunakan untuk melihat bakat dan minat siswa kelas $\mathrm{X}$ terdiri dari tiga tahapan yaitu, tahap awal, tahap kegiatan dan tahap akhir. Adapun penjelasan pada setiap tahapan sebagai berikut: (1) Tahap awal: guru bertindak sebagai ketua kelompok, membuka kegiatan dengan mengajak anggota kelompok untuk melakukan doa bersama, kemudian ketua kelompok menjelaskan materi yang akan dibahas pada hari tersebut. (2) Tahap kegiatan: guru menyampaikan dan menjelaskan materi, dengan menampilkan alat peraga, untuk melihat tingkat ketertarikan anak pada benda yang ditampilkan, kemudian guru menjelaskan kegunaan dari alat peraga yang dipilih oleh anak. (3) Tahap akhir: pemimpin kelompok, bertanya ulang kepada siswa tentang pilihan alat peraga yang dipilih oleh anggota kelompok, kemudian menanyakan fungsinya dan menguji anggota kelompok untuk menggunakan alat peraga dengan tepat. Setelah itu ketua kelompok mengakhiri kegiatan dengan diselingi nyanyian dan berdoa bersama.

Kondisi motivasi belajar siswa SMA diperoleh dari hasil lembar observasi awal di 4 kelas.Siswa kelas X yang menjadi subjek dalam pengambilan data ini berjumlah 15 orang. Kategori yang digunakan untuk menentukan tingkat motivasi belajar siswa adalah Baik Sekali (BS), Baik (B), Cukup Baik (CB), dan Kurang Baik (KB). Berikut ini merupakan hasil dari observasi kondisi awal motivasi belajar siswa kelas $\mathrm{X}$, yaitu: 
TABEL I

KONDISI AWAL MOTIVASI BELAJAR SISWA KELAS X

\begin{tabular}{|c|c|c|c|c|}
\hline No. & $\begin{array}{c}\text { Nama } \\
\text { Peserta } \\
\text { Didik }\end{array}$ & $\begin{array}{c}\text { Frekuensi } \\
\%\end{array}$ & $\begin{array}{c}\text { Nilai Awal } \\
\text { Motivasi } \\
\text { Belajar } \\
\text { Siswa }\end{array}$ & Kategori \\
\hline 1 & FM & $\begin{array}{l}\mathrm{F} \\
\%\end{array}$ & $\begin{array}{l}31 \\
31,00\end{array}$ & KB \\
\hline 2 & DA & $\begin{array}{l}\mathrm{F} \\
\%\end{array}$ & $\begin{array}{l}54 \\
54,00\end{array}$ & $\mathrm{CB}$ \\
\hline 3 & NM & $\begin{array}{l}\mathrm{F} \\
\%\end{array}$ & $\begin{array}{l}55 \\
55,00\end{array}$ & $\mathrm{CB}$ \\
\hline 4 & IA & $\begin{array}{l}\mathrm{F} \\
\%\end{array}$ & $\begin{array}{l}48 \\
48,00\end{array}$ & $\mathrm{CB}$ \\
\hline 5 & HS & $\begin{array}{l}\mathrm{F} \\
\%\end{array}$ & $\begin{array}{l}62 \\
62,00\end{array}$ & $\mathrm{CB}$ \\
\hline 6 & TB & $\begin{array}{l}\mathrm{F} \\
\%\end{array}$ & $\begin{array}{l}76 \\
76,00\end{array}$ & B \\
\hline 7 & $\mathrm{SN}$ & $\begin{array}{l}\mathrm{F} \\
\%\end{array}$ & $\begin{array}{l}67 \\
67,00\end{array}$ & B \\
\hline 8 & $\mathrm{AK}$ & $\begin{array}{l}\mathrm{F} \\
\%\end{array}$ & $\begin{array}{l}83 \\
83,00\end{array}$ & BS \\
\hline 9 & FA & $\begin{array}{l}\mathrm{F} \\
\%\end{array}$ & $\begin{array}{l}80 \\
80,00\end{array}$ & B \\
\hline 10 & RI & $\begin{array}{l}\mathrm{F} \\
\%\end{array}$ & $\begin{array}{l}79 \\
79,00\end{array}$ & B \\
\hline 11 & GE & $\begin{array}{l}\mathrm{F} \\
\%\end{array}$ & $\begin{array}{l}53 \\
53,00\end{array}$ & $\mathrm{CB}$ \\
\hline 12 & MY & $\begin{array}{l}\mathrm{F} \\
\%\end{array}$ & $\begin{array}{l}70 \\
70,00\end{array}$ & B \\
\hline 13 & NO & $\begin{array}{l}\mathrm{F} \\
\%\end{array}$ & $\begin{array}{l}63 \\
63,00\end{array}$ & B \\
\hline 14 & LE & $\begin{array}{l}\mathrm{F} \\
\%\end{array}$ & $\begin{array}{l}75 \\
75,00\end{array}$ & B \\
\hline 15 & JS & $\begin{array}{l}\mathrm{F} \\
\%\end{array}$ & $\begin{array}{l}65 \\
65,00\end{array}$ & B \\
\hline Total & & $\begin{array}{l}\mathrm{F} \\
\%\end{array}$ & $\begin{array}{l}961 \\
64,06\end{array}$ & B \\
\hline
\end{tabular}

Berdasarkan tabel di atas maka dapat disimpulkan bahwa kondisi motivasi belajar siwa kelas X SMA Negeri 2 Pontianak adalah sebesar 961 poin atau dengan presentase $64,06 \%$ dengan kategori baik. Adapun masing-masing kategori terdiri dari kategori baik sekali (BS) sebanyak 1 orang atau sebesar $0,26 \%$, kategori baik (B) sebanyak 8 orang atau sebesar 2,13\%, kategori cukup baik (CB) sebanyak 5 orang atau sebesar $1,33 \%$, dan kurang sekali (KS) sebanyak 1 orang atau sebesar $0,26 \%$, dengan jumlah keseluruhan siswa yang di observasi interaksinya sebanyak 15 orang dari 4 kelas yang tersedia di SMA Negeri 2 Pontianak. Observasi dilakukan dengan menyediakan lembar observasi berjumlah 25 item deskriptor penilaian. Peneliti menyusun model bimbingan kelompok untuk meningkatkan motivasi belajar siswa yang akan dikembangkan terdiri dari 6 komponen utama, sebagai berikut: 1) Rasional, model yang dikembangkan yaitu bimbingan kelompok menggunakan metode problem solving dengan penjabaran secara singkat dan jelas gambaran mengenai motivasi belajar siswa SMA dan gambaran pelaksanaan yang disesuaikan dengan target pencapaian kegiatan bimbingan kelompok yaitu peningkatan motivasi belajar siswa. Dalam rasional dikemukakan aspek-aspek yang menjadi indikator untuk melihat perkembangan motivasi belajar siswa yaitu: (1) ketentuan dalam belajar, (2) ulet dalam menghadapi kesulitan, (3) minat dan ketajaman perhatian dalam belajar, (4) berprestasi dalam belajar, dan (5) mandiri dalam belajar; 2) Visi dan Misi Bimbingan Kelompok merupakan pemberi kejelasan arah pencapaian secara umum layanan bimbingan kelompok; 3) Tujuan Bimbingan Kelompok Berisi tentang tujuan yang ingin dicapai dari pengembangan model bimbingan kelompok dengan metode problem solving. Tujuan ini dibagi menjadi 2, yakni tujuan umum dan tujuan khusus yang keduanya terfokus pada peningkatan motivasi belajar disesuaikan dengan indicator; 4) Isi Bimbingan Kelompok, Isi bimbingan kelompok secara spesifik menjabarkan mengenai ranah pribadi, sosial, belajar dan karir yang hendak dicapai berdasarkan indikator perilaku dalam belajar yang akan diintervensi yaitu motivasi belajar; 5) Pendukung Sistem Bimbingan Kelompok, komponen pendukung sistem bimbingan kelompok merupakan kegiatan manajemen yang diarahkan pada pengembangan program berisi tentang hal-hal yang perlu diperhatikan dalam perencanaan program bimbingan kelompok dengan metode problem solving, pengembangan staf membahas tentang kualifikasi personal dan profesional yang harus dimiliki pemimpin kelompok, penataan kebijakan, prosedur dan petunjuk teknis adalah keterjalinan kerjasama serta dukungan penuh dari stake holder yang ada di sekolah; 6) Tahapan bimbingan Kelompok dengan metode Problem Solving, Dalam bagian bimbingan kelompok dengan metode problem solving ini membahas mengenai tahapan-tahapan dalam pelaksanaan layanan bimbingan kelompok dan evaluasi yang diselenggarakan, berikut penjelasannya: 6.1 Tahapan Bimbingan Kelompok Pada model ini, untuk mencapai tujuan bimbingan kelompok dengan metode problem solving, tahapan-tahapan yang dilaksanakan disesuaikan dengan karakteristik dan perkembangan siswa SMA. Adapun tahapan-tahapan dalam model ini adalah: (1) Tahap permulaan sebagai tahap awal dalam kegiatan bimbingan kelompok yang berisi pengenalan, pengembangan kepekaan dan perlibatan diri, baik dari pemimpin kelompok, teacher shadow dan anggota kelompok, (2) Tahap peralihan merupakan tahap penyesuaian bagi anggota kelompok, tahap dimana pemimpin kelompok memberikan jeda bagi anggota kelompok untuk menyesuaikan diri dengan lingkungan kelompok dan menciptakan dinamika dengan anggota kelompok lainnya, (3) Tahap kegiatan merupakan tahap inti dari kegiatan bimbingan kelompok, pada tahap ini pemimpin kelompok sebagai pemberi instruksi dalam problem solving, memberikan stimulus untuk melihat respon, ekspresi serta komunikasi dari anggota kelompok sebagai indikator dari intervensi yang dikembangkan, (4) Tahap akhir adalah bagian akhir dari bimbingan kelompok yang merupakan tahap terminasi kegiatan kelompok yang ditandai dengan pemimpin kelompok mampu untuk menarik kesimpulan atas keseluruhan rangkaian proses kegiatan dan menindak lanjuti kegiatan kelompok yang selanjutnya akan dilaksanakan. 6.2 Evaluasi Bimbingan Kelompok Berisi tentang rancangan 
penilaian melaui lembar observasi motivasi belajar anggota kelompok untuk mengukur ketercapaian tujuan kegiatan bimbingan kelompok dengan metode problem solving.

Berdasarkan analisis proses kegiatan pengembangan model bimbingan kelompok melalui metode problem solving serta hasil yang telah dicapai oleh anggota kelompok membuktikan bahwa bimbingan kelompok dengan metode problem solving efektif untuk meningkatkan motivasi belajar siswa di kelas X SMA Kota Pontianak. Bimbingan kelompok dengan memanfaatkan dinamika dalam pelaksanaannya, membuat suasana kelompok yang aman dan nyaman, perlahan siswa menjadi semangat dalam mengikuti pembelajaran di sekolah, memiliki kedisiplinan dan tanggung jawab dalam mengerjakan pekerjaan rumah. Siswa mampu menggunakan bahasa verbal dalam mengungkapkan keinginannya baik dalam kegiatan kelompok ataupun diluar kegiatan. Indikasi keberhasilan dari kegiatan bimbingan kelompok yang telah dilaksanakan dapat dilihat dari peran yang dimiliki oleh pemimpin kelompok dan anggota kelompok pada setiap tahapan. Sedangkan untuk efektifitas bimbingan kelompok dapat dibuktikan dari hasil lembar observasi yang menunjukkan adanya peningkatan hasil evaluasi awal dan evaluasi akhir pada skor total motivasi belajar siswa.

TABEL II

KONDISI SISWA SETELAH DIBERIKAN PERLAKUAN

\begin{tabular}{|c|c|c|c|c|c|c|}
\hline $\begin{array}{c}\text { Anggo } \\
\text { ta } \\
\text { Kelo } \\
\text { mpok }\end{array}$ & $\begin{array}{c}\text { Frek } \\
\text { uensi } \\
\%\end{array}$ & $\begin{array}{c}\text { Evalu } \\
\text { asi } \\
\text { Awal }\end{array}$ & $\begin{array}{l}\text { Kate } \\
\text { gori }\end{array}$ & $\begin{array}{c}\text { Evaluasi } \\
\text { Akhir }\end{array}$ & $\begin{array}{c}\text { Kateg } \\
\text { ori }\end{array}$ & $\begin{array}{c}\text { Pening } \\
\text { katan }\end{array}$ \\
\hline NM & $\begin{array}{l}\mathrm{F} \\
\%\end{array}$ & $\begin{array}{l}55 \\
55,00\end{array}$ & CB & $\begin{array}{l}74 \\
74,00\end{array}$ & B & $\begin{array}{l}19 \\
1,27\end{array}$ \\
\hline FA & $\begin{array}{l}\mathrm{F} \\
\%\end{array}$ & $\begin{array}{l}80 \\
80,00\end{array}$ & B & $\begin{array}{l}86 \\
86,00\end{array}$ & BS & $\begin{array}{l}6 \\
0,4\end{array}$ \\
\hline FM & $\begin{array}{l}\mathrm{F} \\
\%\end{array}$ & $\begin{array}{l}31 \\
31,00\end{array}$ & $\mathrm{~KB}$ & $\begin{array}{l}60 \\
60,00\end{array}$ & CB & $\begin{array}{l}29 \\
1,93\end{array}$ \\
\hline DA & $\begin{array}{l}\mathrm{F} \\
\%\end{array}$ & $\begin{array}{l}54 \\
54,00\end{array}$ & $\mathrm{CB}$ & $\begin{array}{l}75 \\
75,00\end{array}$ & B & $\begin{array}{l}21 \\
1,4\end{array}$ \\
\hline RI & $\begin{array}{l}\mathrm{F} \\
\%\end{array}$ & $\begin{array}{l}79 \\
79,00\end{array}$ & B & $\begin{array}{l}90 \\
90,00\end{array}$ & BS & $\begin{array}{l}11 \\
0,73\end{array}$ \\
\hline $\mathrm{AK}$ & $\begin{array}{l}\mathrm{F} \\
\%\end{array}$ & $\begin{array}{l}83 \\
83,00\end{array}$ & BS & $\begin{array}{l}91 \\
91,00\end{array}$ & BS & $\begin{array}{l}8 \\
0,53\end{array}$ \\
\hline Total & $\begin{array}{l}\mathrm{F} \\
\%\end{array}$ & $\begin{array}{l}382 \\
25,46\end{array}$ & $\overline{C B}$ & $\begin{array}{l}476 \\
31,73\end{array}$ & BS & $\begin{array}{l}94 \\
6,27\end{array}$ \\
\hline
\end{tabular}

\section{B. Pembahasan}

Berdasarkan grafik di atas terlihat bahwasanya motivasi belajar pada semua siswa yang menjadi anggota kelompok mengalami peningkatan (nilai evaluasi akhir lebih tinggi dari nilai evaluasi awal). Ketercapaian hasil tersebut karena kegiatan bimbingan kelompok dengan metode problem solving telah dilaksanakan secara profesional sesuai dengan prosedur yang telah direncanakan.

\section{KESIMPULAN}

Bimbingan kelompok dengan metode problem solvingbelum pernah dilaksanakan di SMA Negeri 2 Pontianak, kegiatan yang selama ini dilaksanakan hanya berbentuk kegiatan kelompok. Rumusan model bimbingan kelompok dengan metode problem solving terdiri dari 6 komponen, yakni: (1) Rasional, (2) Visi dan Misi Bimbingan Kelompok, (3)Tujuan Bimbingan Kelompok, (4) Isi Bimbingan Kelompok, (5) Pendukung Sistem Bimbingan Kelompok, dan (6) Tahapan Bimbingan Kelompok dengan metode problem solving. Kelayakan model tersebut telah divalidasi oleh 3 pakar bimbingan dan konseling serta 10 praktisi yaitu guru yang menangani kelas X. Hasil uji kelayakan menunjukkan bahwa model yang dirancang layak untuk diimplementasikan di lapangan. Kondisi obyektif pada 15 siswa kelas X di SMA Negeri 2 diperoleh data sebesar $64,06 \%$ rata-rata siswa berkategori baik, dengan rincian kategori motivasi belajar sebagai berikut: motivasi belajar yang baik sekali (BS) sebanyak 1 orang sebesar $0,26 \%$, kategori baik (B) sebanyak 8 orang atau sebesar 2,13\%, kategori cukup baik (CB) sebanyak 5 orang atau sebesar $1,33 \%$, dan kurang baik (KB) sebanyak 1 orang atau sebesar $0,26 \%$. Model bimbingan kelompok dengan metode problem solving secara efektif dapat meningkatkan motivasi belajar pada semua indikator yang meliputi: ketekunan dalam belajar, ulet dalam menghadapi kesulitan, minat dan ketajaman perhatian dalam belajar, berprestasi dalam belajar, dan, mandiri dalam belajar.

\section{DAFTAR PUSTAKA}

[1] Juntika, A. (2008). Bimbingan \& Konseling dalam Berbagai Latar Kehidupan. Bandung: PT Refika Aditama.

[2] Aunurrahman. (2009). Belajar dan Pembelajaran. Bandung: Alfabeta.

[3] Prayitno. (2009). Pedoman Pengawasan Bimbingan dan Konseling. Jakarta: PT. Remaja Rosdakarya.

[4] Aydin, D. (2009). Efectiveness Of A Group Guidance Program On Realistic Study Field Choice Among First Year High School Students. Jurnal of Education, 5 (1), 67-84.

[5] Driessens, K. (2004). Integrating Guidance into Relational Reinforcement Learning. Jurnal of Education, 34(57), 271-304.

[6] Hoifodt, S.O. \& Talseth, G.A. (2006). A Qualitative Study Of The Learning Processes In Young Physician Streating Suicidal Patients: From Insecurity To Personal Pattern Knowledge and Self-Confidence. Jurnal of Education, 10 (23), 134-143.

[7] Hellen, C. \& Kuruvilla, J. (2011). Effectiveness Of Group Counseling On The Level Of Self-Esteem Of Adolescent School Girls. Jurnal of Education, 2 (3), 28-32.

[8] Sugiyono. (2010). Metode Penelitian Pendidikan. Bandung: Alfabeta. 